\title{
CONCENTRATION OF HYDROXYPROLINE IN TESTES OF HYPOPHYSECTOMIZED PATIENTS BEFORE AND AFTER TREATMENT WITH GONADOTROPHINS AND TESTOSTERONE
}

\author{
BERTA DENDUCHIS, NÉLIDA GÓNZÁLEZ AND \\ ROBERTO E. MANCINI
}

Centro de Investigaciones en Reproducción Facultad de Medicina, Buenos Aires, Argentina

(Received 21st January 1972, accepted 16th March 1972)

Recent studies by Denduchis, Lustig, González \& Mancini (1969) have demonstrated that, in the testes of normal adult men, insoluble collagen from the organ, including tunica albuginea, makes up $99 \%$ of the total collagen. Examination under the light microscope of the seminiferous tubule wall of the testes of hypophysectomized patients revealed the presence of amorphous or slightly fibrillar hyalin material. Electronmicroscope studies carried out by Seiguer, Pérez Lloret \& Mancini (1972) showed that the thickness of the collagen layer adjacent to the basement membrane was markedly increased. Different degrees of deterioration were visible in the collagen fibrils, such as loosening of the collagen strands, poorly defined periodicity and even the absence of cross-banding. In tubules showing slight hyalinization, the spaces between the collagen fibrils appeared to be filled with a slightly homogenous substance; in tubules with severe peritubular hyalinization, the fibrillar network appeared to be almost completely replaced by a similar homogeneous material.

The purpose of this study was to determine the hydroxyproline concentration, in the testes of hypophysectomized patients, either untreated or treated with gonadotrophins, testosterone or both. The hydroxyproline is an imino-acid characteristic of collagen protein and it represents $13.4 \%$ of the collagen molecule.

Testicular biopsies were taken from adult hypophysectomized patients, before and after administration of gonadotrophins, testosterone, or both. The patients had been hypophysectomized for chromophobe adenoma and, after varying periods of time, all of them suffered from impotence and loss of libido. Urinary gonadotrophins were undetectable and urinary levels of 17-keto and hydroxycorticosteroids were low (Mancini, Seiguer \& Pérez Lloret, 1969). Testicular biopsies from normal adult men and testes taken from necropsies of normal adult subjects ( 2 to $3 \mathrm{hr}$ after death) were used as controls. In all cases after removal of the tunica albuginea, the gonads were immediately frozen at $-20^{\circ} \mathrm{C}$ until use.

The testicular biopsies from hypophysectomized patients were classified into two groups, slight and severe, according to the degree of peritubular hyaliniza- 
tion. This process was accompanied by varying degrees of involution of the germinal epithelium and interstitial Leydig cells (Mancini et al., 1969). Doses, hormonal schedule and length of time of administration of gonadotrophins and testosterone have already been reported (Mancini, Seiguer \& Pérez Lloret, 1968; Mancini et al., 1969).

The biopsies were processed as follows: extraction was performed with acetone and ether (three times daily on 3 consecutive days), desiccation being carried out over phosphorous pentoxide. Collagen was extracted from the dry defatted tissue, according to the method of Neuman \& Logan (1950); 2 to 4 $\mathrm{mg}$ of material were used in each case. The different samples of total collagen were hydrolysed in $6 \mathrm{~N}-\mathrm{HCl}$ for $24 \mathrm{hr}$ at $110^{\circ} \mathrm{C}$. The hydrolysates were evaporated in vacuo and neutralized. Hydroxyproline was determined according to the method of Martin \& Axelrod (1953). The concentration of hydroxyproline was expressed as a percentage of the dry weight. Statistical analysis was carried out, using the $t$ test.

TABLE 1

CONCENTRATION OF HYDROXYPROLINE IN TESTES OF NORMAL SUBJECTS AND IN HYALINIZED TESTES OF HYPOPHYSECTOMIZED PATIENTS

\begin{tabular}{l|c|c|c|c}
\hline \multirow{4}{*}{ Males } & $\begin{array}{c}\text { No. of } \\
\text { subjects } \\
\text { or } \\
\text { patients }\end{array}$ & $\begin{array}{c}\text { Source of } \\
\text { testicular } \\
\text { material }\end{array}$ & $\begin{array}{c}\text { Hydraxyproline (mg/100 mg) } \\
\text { mean } \pm \text { S.E. })\end{array}$ & $\begin{array}{c}\text { Peritubular } \\
\text { hyalinization }\end{array}$ \\
\hline Normal & 7 & Biopsy & $2 \cdot 70 \pm 0 \cdot 24$ & None \\
Hypophysectomy & 4 & Necropsy & $2 \cdot 60 \pm 0 \cdot 31$ & None \\
& 13 & Biopsy & $1 \cdot 77 \pm 0 \cdot 13$ & Slight \\
& 3 & Biopsy & $1 \cdot 28 \pm 0.10$ & Severe \\
\hline
\end{tabular}

The values of hydroxyproline corresponding to those of normal testes and those of testes from hypophysectomized patients were separately pooled and are shown in Table 1. The hydroxyproline levels in biopsy and necropsy material were not significantly different, but were different from those reported in a previous paper (Denduchis et al., 1969), where the content of soluble and insoluble collagen of normal adult testes at necropsy was studied. This discrepancy may have been due to the different methodology used.

Values obtained for testes from hypophysectomized patients were lower than testes from normal adults. Testes with slight peritubular hyalinization showed a decrease of $34 \%(P<0.001)$ and those with severe hyalinization, a decrease of $53 \%(P<0.001)$, compared with the values for normal testes. Fabianek \& Herp (1966) demonstrated a similar decrease of collagen content in the dermis of hypophysectomized rats. Recent electronmicroscope studies (Seiguer et al., 1972) showed that formation of the interfibrillar homogeneous substance precedes or appears simultaneously with changes in the collagen fibril structure. The presence of atrophied peritubular fibroblasts was also reported. These findings suggest an alteration in the synthesis of the collagen molecule, probably resulting from a deficiency in an enzyme system (or in its co-factors) which participates in hydroxylation of the prolil residue into large polypeptide pre- 
cursors. However, it is not possible to rule out the presence in this tissue of substances with collagenolytic activity, such as those found in other tissues. Collagenases may initiate the digestion of collagen and form products which are more readily denatured and hence more susceptible to digestion by nonspecific proteases (Sakai \& Gross, 1967). In the reabsorbing tadpole tail, the morphological events seem to be a fraying, swelling and dispersion of the fibre bundles into separate fibrils (Gross, 1964).

TABLE 2

CONCENTRATION OF HYDROXYPROLINE IN TESTES OF HYPOPHYSECTOMIZED PATIENTS AFTER GONADOTROPHIN AND TESTOSTERONE ADMINISTRATION

\begin{tabular}{l|c|c|cc}
\hline \multicolumn{1}{c|}{ Treatment } & $\begin{array}{c}\text { No. of } \\
\text { patients }\end{array}$ & $\begin{array}{c}\text { Hydroxyproline } \\
(\mathrm{mg} / 100 \mathrm{mg})\end{array}$ & $\begin{array}{c}\text { Peritubular hyalinization: } \\
\text { Before } \\
\text { treatment }\end{array}$ & $\begin{array}{c}\text { After } \\
\text { treatment }\end{array}$ \\
\hline HCG & 2 & 2.87 & Slight & None \\
HCG + HMG & 2 & 2.59 & Slight & None \\
HMG +testosterone & 1 & 2.25 & Severe & Slight \\
Testosterone & 1 & 1.83 & Slight & Slight \\
& 2 & 1.10 & Severe & Severe \\
& 1 & 2.09 & Slight & Slight \\
\hline
\end{tabular}

The values for hydroxyproline content obtained after gonadotrophins and testosterone treatment were also separately pooled and the correlated morphological changes in peritubular hyalinization are shown in Table 2 . Where slight or severe hyalinization was treated with HCG or with HCG combined with HMG, the previously low values of hydroxyproline returned to normal levels. These results were coincident with a reduction or disappearance of hyalin deposition. These chemical findings are in accordance with the histological ones previously reported by Mancini et al. (1968), where a marked reduction in the thickness of the hyalin material and a simultaneous reappearance of collagen and elastic fibrils and of normal fibroblasts were detected. These observations suggest that the action of gonadotrophins with LH activity should be present in order to induce a regression in the accumulation of hyalin. This assumption was recently confirmed by the ineffectiveness of purified human urinary FSH to affect hyalinosis when it is used in similar patients (Mancini, Vilar, Donini \& Pérez Lloret, 1971).

The lack of change in the concentration of hydroxyproline and persistence of the hyalinization process when testosterone alone, or HMG together with testosterone, is administered suggests that this steroid is able either to antagonize the favourable effect of HMG upon hyalinosis, or to have no action at all when it is given alone.

Further studies are needed to elucidate the biochemistry of the origin and peritubular formation of the hyalin material in this and other pathological conditions of the human testis and the mechanism by which gonadotrophins may influence such a process. 
This work was supported by a grant from The Population Council Inc., New York.

\section{REFERENCES}

Denduchis, B., Lustig, L., González, N. \& Mancint, R. E. (1969) Physicochemical and immunological study of connective tissue structures of the human testis. Acta Europ. Fert. 1, 595.

Fabianek, J. \& HeRP, A. (1966) Glycoprotein and collagen metabolism in the dermis of hypophysectomized rats. Endocrinology, 78, 1255.

Gross, J. (1964) Studies on the biology of connective tissue: remodelling of collagen in metamorphosis. Medicine, Baltimore, 43, 291.

MANCini, R. E., Seiguer, A. C. \& PERez Lloret, A. (1968) Effect of HMG and HCG on the peritubular hyalinization in testis of hypophysectomized patients. In: Workshop Conference on Gonadotropins. Ed. E. Rosemberg. Geron-X, Los Altos, California.

Mancini, R. E., Seiguer, A. C. \& PÉrez Lloret, A. (1969) Effect of gonadotropins on the recovery of spermatogenesis in hypophysectomized patients. F. clin. Endocr. Metab. 29, 467.

Mancini, R. E., Vilar, O., Donini, P. V. \& Pérez Lloret, A. (1971) Effect of human urinary fsh and LH on the recovery of spermatogenesis in hypophysectomized patients. F. clin. Endocr. Metab. 33, 888.

Martin, C. J. \& Axelrod, A. E. (1953) A modified method for determination of hydroxyproline. Proc. Soc. exp. Biol. Med. 83, 461.

Neuman, R. E. \& Logan, M. A. (1950) The determination of collagen and elastin in tissues. F. biol. Chem. 186, 549.

SAKAI, T. \& Gross, J. (1967) Some properties of the products of reaction tadpole collagenase with collagen. Biochemistry, N.Y. 6, 518.

Seiguer, A. C., Pérez Lloret, A. \& Mancini, R. E. (1972) Electronmicroscopic study of peritubular hyalinization in testis of hypophysectomized patients. Lab. Invest. (in press). 